\title{
FAKTOR RISIKO BALITA STUNTING DI PROVINSI NUSA TENGGARA BARAT
}

\author{
${ }^{1)}$ Irni Setyawati, ${ }^{2)}$ Baiq Nining Handayani, ${ }^{3)}$ Agus Supinganto \\ Program Studi Sarjana Kebidanan, STIKes Yarsi Mataram \\ Jl. TGH. M. Rais Lingkar Selatan - Mataram - Indonesia \\ E-mail : ${ }^{1)}$ erny.gunawan07@gmail.com ${ }^{2)}$ nininghan@gmail.com, ${ }^{3)}$ agusping@gmail.com
}

Kata Kunci:

Risiko, Stunting, NTB

Keywords:

Risk, Stunting, NTB

\section{Info Artikel}

Tanggal dikirim: $12-8-2021$

Tanggal direvisi: $20-8-2021$

Tanggal diterima: 23-1-2022 DOI Artikel:

10.36341/jomis.v6i1.1957

Creative Commons AttributionNonCommercial-ShareAlike 4.0 International License.

\begin{abstract}
ABSTRAK
Usia balita adalah masa emas perkembangan dan pertumbuhan otak bayi yang biasa disebut dengan golden period, khususnya masa 1000 hari pertama. Dibalik pentingnya menjaga pertumbuhan dan perkembangan bayi, terdapat kondisi gagal tumbuh berupa tinggi badan pendek untuk usianya karena kekurangan gizi kronis yang disebut stunting. Provinsi Nusa Tenggara Barat (NTB) mempunyai prevalensi balita pendek lebih tinggi dibandingkan provinsi Bali sebagai provinsi terdekat dari NTB yaitu sebesar 33,5\%, sedangkan provinsi Bali sebesar 21,9\%. Stunting disebabkan oleh macam-macam faktor diantaranya pendidikan ibu, sanitasi, akses ke tempat pelayanan kesehatan, dan infeksi. Penelitian ini bertujuan untuk mengetahui faktor risiko stunting di provinsi NTB. Penelitian ini menggunakan data sekunder Riskesdas provinsi NTB tahun 2018 yang diperoleh dari Badan penelitian dan pengembangan kesehatan (Balitbangkes) Kementerian Kesehatan RI dengan unit analisis anak usia balita 0-59 bulan di provinsi NTB. Data dianalisis secara univariat, bivariat dan multivariat dengan bantuan program SPSS 25,0. Uji bivariat menggunakan uji Chisquare dan uji multivariat menggunakan uji regresi logistik. Penelitian ini menemukan anak usia balita di provinsi NTB mempunyai status gizi normal sebesar $71,2 \%$. Tidak terdapat perbedaan status gizi responden menurut karakteristik anak baik riwayat pernah sakit ataupun jenis kelamin, terdapat perbedaan status gizi responden yang bermakna menurut pendidikan ibu dan jumlah anggota rumah tangga, dan tidak terdapat perbedaan status gizi responden menurut lingkungan. Diharapkan pemerintah provinsi NTB, Dinas Kesehatan Provinsi NTB, BKKBN provinsi NTB, dan Pemerintah kabupaten/kota setempat dapat saling bersinergi melaksanakan program intervensi balita stunting khususnya pada ibu dengan pendidikan rendah dan menengah.
\end{abstract}

\section{ABSTRACT}

Toddler age is a golden period for the development and growth of the baby's brain which is commonly referred to as the golden period, especially the first 1000 days. Behind the importance of maintaining the growth and development of infants, there is a failure to grow in the form of short height for age due to chronic malnutrition called stunting. The province of West Nusa Tenggara (NTB) has a higher prevalence of stunting than the province of Bali as the closest province to NTB, which is $33.5 \%$, while the province of Bali is $21.9 \%$. Stunting is caused by various factors including maternal education, sanitation, access to health care facilities, and infection. This study aims to determine the risk factors for stunting in the province of NTB. This study uses secondary data from Riskesdas for the province of NTB in 2018 obtained from the Health Research and Development Agency (Balitbangkes) of the Indonesian Ministry of Health with an analysis unit for children aged 0-59 months in the province of NTB. Data were analyzed by univariate, bivariate and multivariate with the help of SPSS 25.0 program. Bivariate test using Chi-square test and multivariate test using logistic regression. This study found that children under five in the province of NTB had a normal nutritional status of $71.2 \%$. There were no differences in the nutritional status of the respondents according to the characteristics of the children, either history of illness or gender, there were significant differences in the nutritional status of the respondents according to the mother's education and the number of household members, and there were no differences in the nutritional status of the respondents according to the environment. It is hoped that the NTB provincial government, the NTB Provincial Health Office, the NTB provincial BKKBN, and the local district/city government can synergize with each other in implementing the stunting toddler intervention program, especially for mothers with low and middle education. 


\section{PENDAHULUAN}

Usia balita adalah masa emas perkembangan dan pertumbuhan otak bayi yang biasa disebut dengan golden period, khususnya masa 1000 hari pertama. Masa emas ini menjadi waktu yang penting dalam menciptakan anak yang berkualitas baik secara fisik dan mental. Dibalik pentingnya menjaga pertumbuhan dan perkembangan bayi, terdapat kondisi gagal tumbuh berupa tinggi badan pendek untuk usianya karena kekurangan gizi kronis yang disebut stunting. Setelah balita berusia dua tahun kondisi stunting ini mulai tampak. Balita sangat pendek dan pendek adalah balita yang mempunyai tinggi badan atau panjang badan menurut umur dengan nilai Z-scorenya kurang dari -2SD/standar deviasi (pendek) dan -3SD (sangat pendek) [1].

Stunting mempunyai dampak menetap pada perkembangan motorik dan intelektual bayi yang kurang optimal disebabkan oleh terjadinya perubahan struktur dan fungsi otak bayi serta terganggunya proses pematangan neuron otak bayi [2]. Perkembangan kognitif bayi yang kurang optimal ini mengakibatkan intelligence quotients (IQ) lebih rendah dan hasil prestasi akademik kurang [3].

Indonesia mempunyai prevalensi balita pendek sebesar 37,2\% pada tahun 2013. Prevalensi ini meliputi $18 \%$ balita sangat pendek dan 19,2\% balita pendek [4]. Prevalensi balita pendek menurun pada tahun 2018 yaitu 30,8\% yang meliputi 19,3\% balita pendek dan $11,5 \%$ balita sangat pendek. Provinsi Nusa Tenggara Barat (NTB) mempunyai prevalensi balita pendek lebih tinggi dibandingkan provinsi Bali sebagai provinsi terdekat dari NTB yaitu sebesar 33,5\%, sedangkan provinsi Bali sebesar 21,9\% [5]. Bahkan prevalensi provinsi NTB ini melebihi angka prevalensi balita pendek nasional.

Di Asia Tenggara Indonesia menjadi salah satu negara berkembang. Kejadian stunting di negara berkembang dapat dipengaruhi oleh macam-macam faktor risiko, yaitu status sosial ekonomi keluarga, pendidikan ibu, defisiensi makronutrien dan mikronutrien, dan sanitasi rumah tangga serta pengolahan air [6][7].

Berdasarkan fenomena di atas, peneliti tertarik mengidentifikasi kejadian stunting pada balita di Provinsi NTB, mengidentifikasi faktor karakteristik anak, rumah tangga dan lingkungan balita di Provinsi NTB dan menganalisis faktor risiko kejadian stunting di provinsi NTB tahun 2018.

\section{TINJAUAN PUSTAKA}

Stunting adalah bertumbuh pendek atau kegagalan mencapai potensi pertumbuhan seseorang. Malnutrisi kronis dan penyakit berulang selama masa emas perkembangan dan pertumbuhan otak bayi inilah yang menyebabkan stunting. Keadaan ini mengakibatkan kapasitas fisik dan kognitif anak terbatas secara permanen dan menyebabkan kerusakan yang lama [8]. World Health Organization (WHO) menyatakan bahwa stunting atau terlalu pendek adalah tinggi badan anak lebih dari -2 SD median standar pertumbuhan anak menurut WHO [9].

Stunting (kerdil) merupakan balita yang mempunyai tinggi badan atau panjang badan kurang jika dibandingkan umur. Keadaan ini ditentukan dari panjang badan atau tinggi badan yang kurang dari -2SD median standar pertumbuhan anak dari WHO [10]. Short stature atau perawakan pendek merupakan suatu batasan mengenai tinggi badan yang berada di bawah persentil 3 atau -2 SD pada kurva pertumbuhan yang berlaku pada populasi tersebut [11].

Ada empat faktor yang mempengaruhi stunting yaitu faktor keluarga dan rumah tangga yang terdiri dari maternal dan lingkungan rumah (sanitasi, suplai air, dan akses tempat pelayanan kesehatan), faktor makanan tambahan yang tidak adekuat yang terdiri dari faktor pemberian ASI (ASI eksklusif atau tidak), cara pemberian makanan yang tidak adekuat, kualitas makanan yang rendah, keamanan makan dan minuman, dan yang terakhir faktor infeksi [9]. Trihono menyatakan penyebab stunting di Indonesia 
yang dimodifikasi dari logical framework of the nutritional problems Unicef pada tahun 2013 yaitu terdapat tiga penyebab stunting yaitu penyebab dasar, penyebab tidak langsung, dan penyebab langsung. Pendidikan, disparitas kemiskinan, sosial budaya, kebijakan pemerintah, politik, dan lainnya menjadi penyebab dasar stunting. ketahanan pangan keluarga, pola asuh keluarga, kesehatan lingkungan dan pelayanan kesehatan menjadi penyebab tidak langsung stunting. Asupan gizi yang kurang dan penyakit infeksi merupakan penyebab langsung stunting [12].

Dari beberapa definisi di atas, dapat disimpulkan bahwa stunting ditentukan dari indeks tinggi badan dibandingkan umur berdasarkan Z-score dengan menggunakan rujukan baku WHO dengan kriteria pendek bila nilainya kurang dari minus 2 SD dan sangat pendek bila nilainya kurang dari minus 3 SD. Stunting dipengaruhi oleh macammacam faktor yaitu faktor rumah tangga yang terdiri dari pendidikan ibu dan kemiskinan, faktor lingkungan yang terdiri dari sanitasi dan akses ke tempat pelayanan kesehatan, dan faktor bayi yaitu infeksi. Apriluana dalam literatur reviewnya menyatakan bahwa stunting pada balita di negara berkembang dan Asia Tenggara dipengaruhi oleh berat badan lahir rendah bayi, tingkat pendidikan ibu yang rendah, pendapatan rumah tangga yang rendah, dan kebersihan sanitasi rumah balita yang kurang [13]. Indonesia merupakan salah satu negara berkembang, Provinsi NTB adalah salah satu provinsi di Indonesia. Arini dalam penelitiannya juga menyatakan bahwa penyakit yang pernah diderita balita dapat mempengaruhi kejadian stunting di Surabaya, yaitu frekuensi dan durasi diare dan infeksi pernafasan akut [14]. Setiawan juga menemukan bahwa tingkat asupan energi, lamanya penyakit infeksi, berat badan lahir, tingkat pendidikan ibu dan tingkat pendapatan keluarga mempunyai hubungan yang bermakna dengan kejadian stunting pada anak usia 24-59 bulan di kota Padang [15].

\section{METODE}

Penelitian ini menggunakan data sekunder Riskesdas provinsi NTB tahun 2018 yang didapatkan dari Badan penelitian dan pengembangan kesehatan (Balitbangkes) Kementerian Kesehatan RI. Unit analisis pada penelitian ini adalah anak usia balita 059 bulan di provinsi NTB. Untuk memperoleh data stunting (balita sangat pendek dan pendek) sebagai variabel terikat, data tinggi badan per umur balita diklasifikasikan berdasarkan Z-Score dengan kategori status gizi sangat pendek bila nilai Z-score <-3SD, pendek bila nilai Z-score -3SD sampai dengan <-2SD, normal bila nilai Z-score -2SD sampai dengan $2 \mathrm{SD}$, dan tinggi bila nilai Z-score $>2 S D$. Data sekunder ini dianalisis secara univariat, bivariat dan multivariat dengan bantuan program SPSS 25,0. Analisis univariat dilakukan pada variabel terikat dengan menggunakan distribusi frekuensi. Uji bivariat dilakukan dengan menggunakan uji Chisquare dan uji multivariat menggunakan uji regresi logistik. Penelitian ini dilakukan sejak bulan Maret sampai dengan bulan Juli tahun 2021.

\section{HASIL DAN PEMBAHASAN}

Hasil analisis univariat penelitian ini bertujuan untuk menggambarkan keadaan stunting di provinsi NTB tahun 2018. Adapun hasil univariatnya dapat dilihat pada tabel di bawah ini:

Tabel 1. Distribusi Stunting Responden

\begin{tabular}{lcc}
\hline \multicolumn{1}{c}{ Kategori } & $\mathbf{N}$ & $\mathbf{\%}$ \\
\hline Sangat & 148 & 7,5 \\
pendek (SP) & & \\
Pendek (P) & 385 & 19,5 \\
Normal (N) & 1409 & 71,2 \\
Tinggi (T) & 37 & 1,9 \\
\hline \multicolumn{1}{c}{ Total } & $\mathbf{1 9 9 9}$ & $\mathbf{1 0 0}$ \\
\hline Sumber: Data Riskesdas Provinsi NTB 2018 \\
\multicolumn{2}{l}{ yang telah diolah }
\end{tabular}

Tabel 1 di atas menunjukkan bahwa anak usia balita di provinsi NTB mempunyai status gizi normal sebesar $71,2 \%$, paling sedikit anak usia balita dengan status gizi tinggi sebesar 1,9\%. Anak usia balita di 
provinsi NTB yang mempunyai status gizi pendek sebesar 19,5\% dan sangat pendek sebesar 7,5\%.

Terdapat tiga indeks untuk menilai status gizi balita yaitu berat badan dibandingkan umur, tinggi badan dibandingkan umur, dan berat badan dibandingkan tinggi badan. Indeks tinggi badan dibandingkan umur menggambarkan masalah gizi yang bersifat kronis sebagai akibat dari keadaan yang berlangsung lama. Menurut standar WHO, suatu wilayah dinyatakan berkategori baik bila mempunyai prevalensi balita pendek kurang dari 20\% [16].

Status gizi pendek dapat mengakibatkan kemerosotan jaringan yang disebabkan oleh penggunaan cadangan gizi dalam tubuh akibat kurangnya asupan gizi. Kemerosotan

Tabel 2. Status Gizi Responden menurut Karakteristik Anak, Rumah Tangga, dan Lingkungan

\begin{tabular}{|c|c|c|c|c|c|c|c|c|c|c|}
\hline \multirow{3}{*}{$\begin{array}{c}\text { Variabel \& } \\
\text { Kategori }\end{array}$} & \multicolumn{8}{|c|}{ Status Gizi } & \multirow{3}{*}{ Nilai $p$} & \multirow{3}{*}{$\begin{array}{c}\text { OR (IK } \\
95 \%)\end{array}$} \\
\hline & \multicolumn{2}{|c|}{ Sangat pendek } & \multicolumn{2}{|c|}{ Pendek } & \multicolumn{2}{|c|}{ Normal } & \multicolumn{2}{|c|}{ Tinggi } & & \\
\hline & $\mathbf{n}$ & $\%$ & $\mathbf{n}$ & $\%$ & $\mathbf{n}$ & $\%$ & $\mathbf{n}$ & $\%$ & & \\
\hline \multicolumn{11}{|c|}{ Karakteristik Anak } \\
\hline \multicolumn{11}{|c|}{ Pernah sakit } \\
\hline $\mathrm{Ya}$ & 9 & 6,1 & 11 & 2,9 & 70 & 4,9 & 3 & 8,1 & \multirow[t]{2}{*}{0,276} & $0, / 3(0,44-$ \\
\hline Tidak* & 139 & 93,9 & 374 & 97,1 & 1339 & 95,1 & 34 & 91,8 & & \\
\hline \multicolumn{10}{|l|}{ Jenis kelamin } & \multirow{3}{*}{$\begin{array}{c}1,21(0,99 \\
1,47)\end{array}$} \\
\hline Perempuan & 66 & 44,6 & 176 & 45,7 & 707 & 50,2 & 17 & 45,9 & \multirow[t]{2}{*}{0,073} & \\
\hline Laki-laki* & 82 & 55,4 & 209 & 54,3 & 702 & 49,8 & 20 & 59,5 & & \\
\hline
\end{tabular}

Karakteristik Rumah Tangga

Pendidikan ibu

Tidak sekolah

\begin{tabular}{|c|c|c|c|c|c|c|c|c|c|c|}
\hline Tidak sekolah & 7 & 4,7 & 17 & 4,4 & 38 & 2,7 & 3 & 8,1 & 0,0001 & $\begin{array}{c}0,96(0,69- \\
1,32)\end{array}$ \\
\hline $\begin{array}{l}\text { Tidak tamat } \\
\text { SD }\end{array}$ & 16 & 10,8 & 23 & 5,9 & 129 & 9,2 & 4 & 10,8 & 0,096 & $\begin{array}{c}1,50(0,90- \\
2,48)\end{array}$ \\
\hline Tamat SD & 37 & 25 & 108 & 28,1 & 253 & 17,9 & 4 & 10,8 & 0,0001 & $\begin{array}{c}2,88(1,95- \\
4,27)\end{array}$ \\
\hline Tamat SLTP & 37 & 25 & 85 & 22,1 & 294 & 20,9 & 10 & 27,1 & 0,0002 & $\begin{array}{c}2,05(1,38- \\
3,05)\end{array}$ \\
\hline Tamat SLTA & 43 & 29,1 & 114 & 29,6 & 469 & 33,3 & 7 & 18,9 & 0,005 & $\begin{array}{c}1,69(1,15- \\
2,47)\end{array}$ \\
\hline Tamat PT* & 8 & 5,4 & 38 & 44,7 & 226 & 16,0 & 9 & 24,3 & & \\
\hline \multicolumn{11}{|c|}{ Jumlah anggota rumah tangga } \\
\hline $\begin{array}{l}\text { Besar (>6 } \\
\text { orang) }\end{array}$ & 12 & 8,1 & 41 & 10,6 & 99 & 7,0 & 6 & 16,2 & 0,03 & $\begin{array}{c}1,11(0,9- \\
1,36)\end{array}$ \\
\hline $\begin{array}{l}\text { Menengah }(5- \\
6 \text { orang) }\end{array}$ & 38 & 25,7 & 113 & 29,4 & 474 & 33,6 & 9 & 24,3 & 0,02 & $\begin{array}{c}0,76(0,60- \\
0,96)\end{array}$ \\
\hline $\begin{array}{l}\text { Kecil }(<5 \\
\text { orang)* }\end{array}$ & 98 & 66,2 & 231 & 60 & 836 & 59,3 & 22 & 59,5 & & \\
\hline
\end{tabular}

jaringan ini ditandai dengan pertumbuhan tinggi badan yang terhambat. Jumlah zat gizi yang dikonsumsi dan keberadaan gangguan merupakan faktor penentu pemanfaatan zat gizi dalam tubuh [17].

Tabel 2 di bawah ini menunjukkan hasil analisis bivariat yang menggambarkan beberapa faktor risiko yang mempengaruhi kejadian stunting di provinsi NTB. 


\begin{tabular}{lcccccccccc}
\hline $\begin{array}{l}\text { Lingkungan } \\
\text { Akses pelayanan kesehatan }\end{array}$ & & & & & & & & \\
Ada & 145 & 97,9 & 382 & 99,2 & 1400 & 99,4 & 37 & 100 & 0,394 & $0,55(0,19-$ \\
Tidak ada* & 3 & 2,1 & 3 & 0,8 & 9 & 0,6 & 0 & 0 & & $1,55)$ \\
$\begin{array}{l}\text { Cara membuang tinja anak } \\
\text { Di jamban }\end{array}$ & 53 & 35,8 & 178 & 46,2 & 572 & 40,6 & 15 & 40,5 & 0,30 & $1,18(0,92-$ \\
Lainnya* & 95 & 64,2 & 207 & 53,8 & 836 & 59,4 & 22 & 59,5 & & $1,37)$ \\
\hline
\end{tabular}

Sumber: Data Riskesdas Provinsi NTB tahun 2018 yang telah diolah dengan uji Chi Kuadrat, nilai kemaknaan $\mathrm{p}<0,05$

\section{Karakteristik anak}

Tabel 2 di atas menunjukkan bahwa tidak terdapat perbedaan status gizi responden menurut karakteristik anak baik riwayat pernah sakit ataupun jenis kelamin yang dibuktikan dengan nilai $\mathrm{p}>0,05$. Riwayat pernah sakit pada penelitian ini yaitu riwayat sakit infeksi saluran pernapasan atas (ISPA) dalam satu bulan terakhir. Semua balita di provinsi NTB sebagian besar tidak sakit ISPA dan tidak ada perbedaan status gizi pada kategori sangat pendek, pendek, normal dan tinggi menurut riwayat sakit balita. ISPA merupakan penyakit saluran pernapasan akut yang mempunyai gejala demam, batuk, pilek, nyeri tenggorokan, dan sesak nafas. Balita sering mengalami ISPA. ISPA bukan merupakan penyakit yang berbahaya, namun bila tidak ditangani dengan cepat dan tepat dapat menyebabkan radang paru yang dapat berakibat kematian dalam jangka waktu panjang [18]. Penelitian Sunarni di Ciamis menemukan ada hubungan yang bermakna antara status gizi dan ISPA, namun dalam penelitian tersebut menjelaskan status gizi yang kurang dapat menyebabkan balita mudah mengalami ISPA [19]. Demikian juga yang ditemukan oleh Arini di Surabaya bahwa terdapat hubungan yang bermakna antara frekuensi infeksi pernapasan akut dan durasi infeksi pernafasan akut menurut status gizinya (sangat pendek, pendek, dan normal). Batita yang pendek sering mengalami infeksi pernafasan akut dibandingkan status gizi normal, sedangkan batita yang normal jarang dan tidak pernah mengalami infeksi saluran pernafasan akut. Demikian juga dengan durasinya, batita yang pendek mengalami infeksi saluran pernafasan akut yang lama, sedangkan batita yang status gizinya normal mengalami infeksi pernafasan akut yang tidak lama [14]. Setiawan di Padang Timur tahun
2018 menemukan terdapat hubungan yang bermakna antara riwayat penyakit infeksi dan kejadian stunting [15].

Hasil ini berbeda dengan hasil Supariasa di Malang tahun 2019 yang menemukan proporsi balita stunting dan balita normal yang pernah sakit infeksi hampir sama yaitu 82\% (normal) dan $80 \%$ (stunting) [20]. Penelitian ini mempunyai hasil yang sama yaitu tidak terdapat perbedaan status gizi menurut riwayat pernah sakit infeksi dalam 1 bulan terakhir. Hal ini dapat terjadi disebabkan oleh penyakit infeksi yang dialami bayi tidak menyebabkan terganggunya status gizi dalam jangka waktu yang lama, sehingga tidak terjadi perubahan status gizi yang signifikan.

Pada penelitian ini ditemukan tidak terdapat hubungan yang bermakna status gizi balita menurut jenis kelamin. Tidak adanya perbedaan ini dapat disebabkan oleh proporsi status gizi balita menurut jenis kelamin yang tidak konsisten. Hal ini ditunjukkan dengan proporsi balita sangat pendek dan pendek lebih banyak pada balita laki-laki dibandingkan perempuan, sedangkan pada proporsi balita normal lebih banyak pada balita perempuan dibandingkan laki-laki, dan sebaliknya proporsi balita tinggi lebih banyak pada balita laki-laki dibandingkan perempuan. Penelitian Savita di Bangka Selatan juga menemukan hasil yang sama yaitu tidak terdapat hubungan yang bermakna antara kejadian stunting dan jenis kelamin balita umur 6-59 bulan [21].

\section{Karakteristik rumah tangga}

Terdapat perbedaan status gizi responden yang bermakna menurut karakteristik rumah tangga yang terdiri dari pendidikan ibu tidak sekolah dengan nilai $\mathrm{p}<0,05$ dengan faktor risiko 0,96 kali lipat dibandingkan ibu tamat PT, pendidikan ibu tamat SD juga mempunyai 
perbedaan bermakna dengan nilai $\mathrm{p}<0,05$ dan berfaktor risiko 2,88 kali lipat dibandingkan tamat PT, pendidikan ibu tamat SLTP juga mempunyai perbedaan bermakna yang ditunjukkan dengan nilai $\mathrm{p}<0,05$ dan mempunyai faktor risiko 2,05 kali lipat dibandingkan ibu tamat PT, dan pendidikan ibu tamat SLTA mempunyai perbedaan bermakna dengan nilai $\mathrm{p}<0,05$ dan berfaktor risiko 1,69 kali lipat dibandingkan ibu tamat PT.

Hasil penelitian ini selaras dengan hasil Setiawan di Padang Timur tahun 2018 yang memperoleh hasil terdapat hubungan bermakna antara tingkat pendidikan ibu dan kejadian stunting, ibu dengan pendidikan rendah mempunyai faktor risiko 9,9 kali lipat terjadi stunting dibandingkan ibu dengan pendidikan tinggi [15]. Analisis Apriluana di negara berkembang juga menyatakan bahwa ibu yang tidak menyelesaikan pendidikan dasar mempunyai faktor risiko kejadian stunting 1,67 kali lipat dibandingkan ibu yang tamat SLTA [6]. Pendidikan menengah atau tinggi diikuti oleh pengetahuan ibu tentang ASI eksklusif, makanan pendamping ASI, dan pemantauan pertumbuhan dan perkembangan bayi yang baik. Pengetahuan yang baik akan diimbangi dengan motivasi dan perilaku ibu dalam memberikan asupan nutrisi sesuai kebutuhan bayi pada usianya.

Perbedaan status gizi responden yang bermakna menurut jumlah anggota rumah tangga baik besar ( $>6$ orang) dan menengah (5-6 orang) ditunjukkan dengan nilai $\mathrm{p}<0,05$, jumlah anggota rumah tangga $>6$ orang mempunyai faktor risiko 1,11 kali lipat dibandingkan jumlah anggota rumah tangga $<5$ orang, dan jumlah anggota rumah tangga 56 orang mempunyai faktor risiko 0,76 kali lipat dibandingkan jumlah anggota rumah tangga $<5$ orang. Hasil penelitian ini didukung oleh penelitian Fikadu di Ethiopia Selatan yang menemukan ukuran keluarga yaitu keluarga yang beranggotakan 8-10 orang dan jumlah balita 2-3 orang dalam satu keluarga merupakan faktor terjadinya stunting pada anak 24-59 bulan [7].

Jumlah anggota rumah tangga mempengaruhi kemampuan daya beli keluarga dalam memenuhi kebutuhan pangan setiap harinya, baik dalam segi jumlah dan kualitasnya.
Jumlah anggota rumah tangga yang semakin banyak mengakibatkan kebutuhan pangan di dalam sebuah rumah tangga semakin banyak pula, sehingga semakin sedikit jumlah dan kualitas yang diperoleh masing-masing anggota rumah tangga. Asupan gizi yang kurang dari kebutuhan gizi pada balita dapat menyebabkan stunting [20]. Jumlah anggota rumah tangga yang banyak mempengaruhi variasi pola konsumsi karena selera konsumsi masing-masing anggota rumah tangga tidak sama. Semakin banyak anggota rumah tangga maka semakin banyak pula proporsi pengeluaran makanan rumah tangga. Jumlah anggota rumah tangga berhubungan dengan penghasilan rumah tangga yang mempengaruhi pola konsumsinya [22].

Hasil ini tidak selaras dengan hasil Setiawan di Padang Timur tahun 2018 yang memperoleh hasil tidak terdapat hubungan bermakna antara jumlah anggota rumah tangga dan kejadian stunting [15]. Ketidakselarasan hasil ini dapat disebabkan oleh faktor lain yang mempengaruhi dan perbedaan karakteristik responden.

\section{Lingkungan}

Hasil penelitian ini menemukan bahwa tidak terdapat perbedaan status gizi responden menurut lingkungan baik akses pelayanan kesehatan dan cara membuang tinja anak yang ditunjukkan dengan nilai $p>0,05$. Tidak terdapatnya perbedaan status gizi menurut lingkungan pada penelitian ini dapat disebabkan oleh faktor lain yang lebih mempengaruhi perbedaan status gizi.

Akses pelayanan kesehatan pada penelitian ini dilihat dari pengetahuan keberadaan tempat pelayanan kesehatan terdekat (baik rumah sakit atau puskesmas). Ketersediaan tempat pelayanan kesehatan terdekat berhubungan dengan kemampuan rumah tangga dalam mengaksesnya. Penelitian Dewi di Buton Tengah menemukan terdapat hubungan yang bermakna antara kejadian stunting dan pemanfaatan pelayanan kesehatan yang ditunjukkan dengan balita yang mengalami stunting merupakan balita yang kurang memanfaatkan pelayanan kesehatan, sedangkan balita yang tidak stunting merupakan balita yang memanfaatkan pelayanan kesehatan dengan cukup [23]. 
Faktor cara membuang tinja anak pada penelitian ini terbagi menjadi membuang di jamban dan lainnya atau selain jamban (baik ditanam, di sembarang tempat, di tempat sampah, dan lain-lain). Penelitian ini menemukan semua balita (status gizi sangat pendek, pendek, normal, dan tinggi) mempunyai proporsi pembuangan tinjanya di selain jamban lebih banyak dibandingkan di jamban. Hal ini menunjukkan bahwa perilaku ibu dan anggota rumah tangga yang lain dalam menjaga kebersihan balitanya masih kurang. Apriluana dalam analisisnya menyatakan bahwa rumah tangga yang tidak mempunyai akses sanitasi memiliki risiko balita stunting sebesar 1,04 kali lipat, demikian juga dengan rumah tangga yang tidak mempunyai fasilitas air di rumah memiliki risiko balita stunting sebesar 5 kali lipat, dan rumah tangga yang minum air tanpa diolah memiliki risiko balita stunting sebesar 3,47 kali lipat [6]. Kebersihan lingkungan balita yang kurang baik dapat menyebabkan munculnya berbagai penyakit yang mempengaruhi kesehatan balita, seperti diare, kecacingan, dan infeksi saluran pencernaan

[20].

Di bawah ini hasil seleksi analisis bivariat yang berisi variabel yang akan dimasukkan ke dalam analisis multivariabel:

Tabel 3. Hasil Seleksi Analisis Bivariabel Calon Model Analisis Multivariabel

\begin{tabular}{clcc}
\hline No & \multicolumn{1}{c}{ Variabel } & Nilai p & OR (IK 95\%) \\
\hline 1 & Karakteristik Anak & 0,073 & $1,21(0,99-1,47)$ \\
& Jenis kelamin perempuan & & \\
2 & Karakteristik Rumah Tangga & 0,0001 & $0,96(0,69-1,32)$ \\
& Pendidikan Ibu tidak sekolah & 0,096 & $1,50(0,90-2,48)$ \\
& Pendidikan ibu tidak tamat SD & 0,0001 & $2,88(1,95-4,27)$ \\
& Pendidikan ibu tamat SD & 0,0002 & $2,05(1,38-3,05)$ \\
& Pendidikan ibu tamat SLTP & 0,005 & $1,69(1,15-2,47)$ \\
& Pendidikan ibu tamat SLTA & 0,03 & $1,11(0,9-1,36)$ \\
& Jumlah anggota rumah tangga besar (>6) & & $0,76(0,60-0,96)$ \\
\hline
\end{tabular}

Dari hasil seleksi yang ditunjukkan oleh tabel

3 di atas dapat dilihat bahwa terdapat delapan variabel yang dapat dimasukkan ke dalam analisis multivariabel dengan faktor karakteristik anak yang hanya mengikutsertakan jenis kelamin perempuan dan faktor karakteristik rumah tangga yang terdiri dari pendidikan ibu tidak sekolah, tidak tamat SD, tamat SD, tamat SLTP, tamat SLTA, jumlah anggota rumah tangga kategori besar ( $>6$ orang) dan jumlah anggota rumah tangga menengah (5-6 orang).

Hasil akhir dari analisis multivariabel pada penelitian ini ditunjukkan oleh tabel di bawah ini:

Tabel 4. Analisis Multivariat Status Gizi berdasarkan Karakteristik Anak, Karakteristik Rumah Tangga, dan Lingkungan di NTB secara Bersama-sama

\begin{tabular}{lcccc}
\hline \multicolumn{1}{c}{ Variabel } & Koefisien B & S.E $(\mathbf{B})$ & Nilai p & OR (IK 95\%) \\
\hline Pendidikan ibu tamat SLTA & $-0,670$ & 0,247 & 0,007 & $0,51(0,32-0,83)$ \\
Pendidikan ibu tamat SLTP & $-0,859$ & 0,245 & 0,00001 & $0,42(0,23-0,69)$ \\
Konstanta & 1,950 & & & \\
\hline Sun & & & \\
\hline
\end{tabular}

Sumber: Data Riskesdas Provinsi NTB tahun 2018 yang telah diolah dengan uji Regresi Logistik

Berdasarkan hasil analisis variabel bebas secara bersama-sama pada tabel 4 di atas, variabel yang berpengaruh secara bermakna terhadap risiko status gizi anak usia balita adalah pendidikan ibu tamat SLTA/MA dan pendidikan ibu tamat SLTP/MTs dengan nilai 
$\mathrm{p}<0,05$. Pendidikan ibu tamat SLTA/MA mempunyai risiko 0,51 kali lipat dan pendidikan ibu tamat SLTP/MTs mempunyai risiko 0,42 kali lipat.

Hasil analisis di atas menunjukkan bahwa pendidikan ibu tamat SLTA/MA dan pendidikan ibu tamat SLTP/MTs merupakan faktor paling berisiko menyebabkan balita stunting di provinsi NTB tahun 2018 dibandingkan faktor-faktor yang lain. Pendidikan ibu merupakan faktor yang paling penting karena ibu merupakan guru pertama bagi anak sebagaimana keluarga merupakan pendidikan pertama. Pendidikan ibu yang tingi memudahkan ibu dalam menerima dan memahami informasi tentang cara mengolah makanan, cara memberikan makanan pada anak, cara menjaga kebersihan dan kesehatan anak, dan lain-lain sehingga ibu mampu mengaplikasikan informasi yang diterimanya dengan baik. Perilaku pengasuhan balita yang baik oleh ibu inilah yang dapat mencegah terjadinya stunting pada balita [24].

\section{KESIMPULAN}

Sebagian besar balita di provinsi NTB mempunyai status gizi normal, meskipun ditemukan sebagian kecil yang mengalami status gizi pendek dan sangat pendek. Sebagian besar balita tidak pernah sakit dan berjenis kelamin laki-laki. Sebagian besar ibu balita berpendidikan terakhir SLTA dan mempunyai jumlah anggota rumah tangga kurang dari 5 orang (keluarga kecil). Sebagian besar keluarga balita mempunyai akses ke tempat pelayanan kesehatan dan mempunyai kebiasaan membuang tinja balita di selain jamban. Pendidikan ibu dan jumlah anggota rumah tangga lebih dari sama dengan 5 orang menjadi faktor risiko paling dominan dengan kejadian balita stunting. Pendidikan ibu tamat SLTA dan SLTP mempunyai risiko 0,51 kali lipat terjadi balita stunting di provinsi NTB. Dari kesimpulan di atas, diharapkan Pemerintah provinsi NTB, Dinas Kesehatan provinsi NTB, BKKBN provinsi NTB, dan Pemerintah Kabupaten/kota se-NTB dapat saling bersinergi dalam melaksanakan program intervensi stunting khususnya pada ibu balita yang berpendidikan rendah dan menengah serta keluarga yang beranggotakan lebih dari sama dengan 5 orang.

\section{DAFTAR PUSTAKA}

[1] Timnasionalpercepatankemiskinan, "100 kabupaten/kota prioritas untuk intervensi anak kerdil (stunting) ringkasan,” Jakarta, 2017.

[2] A. Yadika, K. Berawi, and S. Nasution, "Pengaruh stunting terhadap perkembangan kognitif dan prestasi belajar," Majority, pp. 273-282, 2019.

[3] A. Daracantika, Ainin, and Besral, "Systematic literature review: Pengaruh negatif stunting terhadap perkembangan kognitif anak," Bikfokes, vol. 1, no. 2, pp. 124-135, 2021.

[4] B. KemenkesRI, "Riset kesehatan dasar 2013," Jakarta, 2013.

[5] Kementerian Kesehatan RI, "Laporan nasional riskesdas 2018," Jakarta, 2018.

[6] G. Apriluana and S. Fikawati, "Analisis Faktor-Faktor Risiko terhadap Kejadian Stunting pada Balita (0-59 Bulan) di Negara Berkembang dan Asia Tenggara," Media Penelit. dan Pengemb. Kesehat., 2018, doi: 10.22435/mpk.v28i4.472.

[7] I. Budiastutik and M. Z. Rahfiludin, "Faktor Risiko Stunting pada anak di Negara Berkembang Risk Factors of Child Stunting in Developing Countries," Amerta Nutr., 2019.

[8] I. Unicef, "Nutrisi mengatasi beban ganda malnutrisi di Indonesia," 2014. https://www.unicef.org/indonesia/id/nu trisi.

[9] WHO, "Global nutrition targets 2025: stunting policy brief," Geneva, 2014. [Online]. Available: https://www.who.int/nutrition/publicati ons/globaltargets2025_policybrief_stun ting/en/.

[10] P. KemenkesRI, "Situasi balita pendek (stunting) di Indonesia," Jakarta, 2018.

[11] KemenkesRI, Pedoman pelaksanaan stimulasi, deteksi dan intervensi dini tumbuh kembang anak di tingkat 
pelayanan kesehatan dasar. Jakarta, 2015.

[12] et al Trihono, Pendek (stunting) di Indonesia, masalah dan solusinya. Jakarta: Balitbangkes, 2015.

[13] G. Apriluana, "Analisis faktor-faktor risiko terhadap kejadian stunting pada balita (0-59 bulan) di negara berkembang dan Asia Tenggara," Media Penelit. dan Pengemb. Kesehat., vol. 28, no. 4, pp. 247-256, 2018, [Online]. Available: ejournal2.litbang.kemenkes.go.id.

[14] D. Arini, N. Nursalam, M. Mahmudah, and I. Faradilah, "The incidence of stunting, the frequency/duration of diarrhea and acute respiratory infection in toddlers," J. Public health Res., vol. 9, no. 1816, pp. 117-120, 2020.

[15] E. Setiawan, R. Machmud, and M. Masrul, "Faktor-Faktor yang Berhubungan dengan Kejadian Stunting pada Anak Usia 24-59 Bulan di Wilayah Kerja Puskesmas Andalas Kecamatan Padang Timur Kota Padang Tahun 2018," J. Kesehat. Andalas, 2018, doi: 10.25077/jka.v7i2.813.

[16] D. KemenkesRI, "Buku saku pemantauan status gizi tahun 2017," Jakarta, 2017.

[17] H. M. Par'i, S. Wiyono, and T. P. Harjatmo, Bahan ajar gizi: Penilaian status gizi. Jakarta: Kemenkes RI, 2017.

[18] S. Widianti, "Penanganan ispa pada anak balita," J. Kesehat. dan Pembang., vol. 10, no. 20, pp. 79-88, 2020.

[19] N. Sunarni, R. Litasari, and L. Deis,
"Hubungan status gizi dengan kejadian ISPA pada balita di wilayah kerja puskesmas Margaharja Sukadana Ciamis," J. Ris. Kebidanan Indones., vol. 1, no. 2, pp. 70-75, 2017.

[20] I. D. N. Supariasa and H.

Purwaningsih, "Faktor-faktor yang mempengaruhi kejadian stunting pada balita di kabupaten Malang," Karta Rahardja, vol. 1, no. 2, pp. 55-64, 2019, [Online]. Available: http://ejurnal.malangkab.go.id/index.ph $\mathrm{p} / \mathrm{kr} /$ article/view/21/14.

[21] R. Savita and F. Amella, "Hubungan pekerjaan ibu, jenis kelamin, dan pemberian ASI eksklusif terhadap kejadian stunting pada balita 6-59 bulan di Bangka Selatan," J. Kesehat. Poltekkes Kemenkes RI

Pangkalpinang, vol. 8, no. 1, pp. 1-8, 2020.

[22] I. K. A. P. Sanjaya and M. H. U. Dewi, "Analisis pengaruh pendapatan, jumlah anggota keluarga dan pendidikan terhadap pola konsumsi rumah tangga miskin di desa Bebandem, Karangasem," E-Jurnal EP Unud, vol. 6, no. 8, pp. 1573-1600, 2017.

[23] I. Dewi, Suhartatik, and Suriani, "Faktor yang mempengaruhi kejadian stunting pada balita 24-60 bulan di wilayah kerja puskesmas Lakudo kabupaten Buton Tengah," J. Ilm. Kesehat. Diagnosis, vol. 14, no. 1, pp. 85-90, 2019.

[24] Nurmaliza and S. Herlina, "Hubungan pengetahuan dan pendidikan ibu terhadap status gizi balita," J. Kesmas, vol. 1, no. 1, pp. 44-48, 2018. 